\title{
A single nucleotide polymorphism in exon 7 of sorbin and SH3-domain-containing-1 (SORBS1) in Korean PCOS patients
}

\author{
JUNG-MI PARK ${ }^{1}$, BON-HEE GU ${ }^{1}$, EUNG-JI LEE ${ }^{1}$, JAE-YOUNG KIM ${ }^{1}$, \\ SUNG-WOO $\mathrm{CHOI}^{2}$ and KWANG-HYUN BAEK ${ }^{1}$ \\ ${ }^{1}$ Graduate School of Life Science and Biotechnology, Cell and Gene Therapy Research Institute, Pochon CHA University, \\ CHA General Hospital, Seoul 135-081, Korea; ${ }^{2}$ Phillips Exeter Academy, Exeter, NH, USA
}

Received October 19, 2007; Accepted November 20, 2007

\begin{abstract}
Patients with polycystic ovarian syndrome (PCOS) are characterized by high levels of androgens, irregular or no menstrual cycle and increased hair growth. In addition, insulin resistance and glucose tolerance are caused in patients with PCOS. It was recently reported that PCOS in women is associated with a single nucleotide polymorphism (SNP) of genes, including the sorbin and SH3-domain-containing-1 (SORBS1) gene involved in insulin resistance and glucose uptake. SORBS1, which belongs to the sorbin homology (SoHo) family of proteins, becomes protein-protein interaction through three SH3 domains. In addition, SORBS1 is related to $\mathrm{c}-\mathrm{Cbl}$-associated protein (CAP) that has interacted with the downstream signaling components of glucose uptake. We therefore studied the association between the SNP of the SORBS1 gene and PCOS in a Korean population. SORBS1 raises glucose uptake and insulin resistance. The frequency of $G$ allele was slightly higher in the patient group $(n=233)$ than in the control group $(n=105)$. A statistically significant relationship was found between the SNP in exon 7 of the SORBS1 gene and PCOS in a Korean population group.
\end{abstract}

\section{Introduction}

Polycystic ovarian syndrome (PCOS) is a heterogeneous hormonal disorder that affects a woman's menstrual cycle, fertility, hormone production, insulin resistance and obesity (1-3). Women with PCOS have aberrant glucose tolerance, hyperandrogenism and diabetes mellitus $(3,4)$. They are characterized by high levels of androgens, irregular or no menstrual cycle and hirsutism, as well as by significant metabolic abnormities such as glucose-stimulated hyperinsulinemia, abnormality of expenditure energy and dyslipidemia

Correspondence to: Dr Kwang-Hyun Baek, Graduate School of Life Science and Biotechnology, Pochon CHA University, CHA General Hospital, 606-16 Yeoksam 1-dong, Kangnam-gu, Seoul 135-081, Korea

E-mail: baek@cha.ac.kr

Key words: insulin resistance, polycystic ovary syndrome, single nucleotide polymorphism, sorbin and SH3-domain-containing-1
(3). It has been reported that approximately $4.9 \%$ of female college students in Korea have exhibited PCOS (5). In women of other ethnic groups, that number has been reported as $4-12 \%(1,6,7)$.

Recently, various single nucleotide polymorphisms (SNPs) have been investigated by means of linkage and association studies in women with PCOS. A number of SNPs associated with PCOS have been reported (8-20), as have cases of PCOS related to the target genes of glucose uptake and insulin resistance. Insulin receptor substrate-1 (IRS-1) and -2 (IRS-2) play key roles in the pathogenesis of PCOS $(10,11)$. In addition, it has been reported that IRS-1 (Gly ${ }^{972} \mathrm{Arg}$ ) and -2 (Gly $\left.{ }^{1057} \mathrm{Asp}\right)$ influence type- 2 diabetes; patients with these polymorphisms revealed phenotypic features of PCOS (12). A recent study indicated that the insulin and insulin receptor gene is a genetic factor, as women with PCOS have increased type-2 diabetes (8). Other research has indicated that $C Y P 17$, encoding for the enzyme P450c17, is associated with the pathogenesis of PCOS (13-17). Previous reports have shown that the Pro12Ala variant of the PPAR $\gamma$ gene, a gene associated with insulin resistance and glucose tolerance in Caucasian woman with PCOS $(18,19)$, is a key component of the pathogenesis of PCOS $(18,19)$. Consequently, insulin resistance is of importance in various disorders including obesity, diabetes mellitus, glucose tolerance and hypertension, and an investigation of the SNPs of genes involved in glucose uptake and insulin resistance will aid in the clinical therapy of patients with PCOS.

It was recently suggested that clinical and biochemical variability in PCOS patients is caused by environmental and genetic factors, including glucose uptake and insulin resistance $(20,21)$. Previous reports suggest that the candidate genes of women with PCOS are involved in insulin-mediated glucose transport, obesity and type-2 diabetes (20-26). We therefore hypothesized that downstream signaling proteins, such as insulin-mediated glucose transport, obesity and type- 2 diabetes, were involved in this disorder.

The binding of insulin to its receptor activates the phosphorylation of insulin receptor and downstream signaling molecules. One of these downstream signaling components is $\mathrm{c}-\mathrm{Cbl}$, which is involved in glucose uptake and interacts with c-Cbl-associated protein (CAP), encoded by the sorbin and SH3-domain-containing-1 (SORBS1) gene (20). The SORBS1 gene, also called CAP, SH3P12 or Ponsin, is one of the candidate genes for the pathogenesis of PCOS and is expressed 
in sensitive tissues such as the adipose tissues, skeletal muscles and liver (21-23). SORBS1 belongs to the sorbin homology (SoHo) family of proteins and is involved in protein-protein interaction through three SH3 domains (20-23). Following the insulin stimulation and phospholyation of Cbl, CAP-Cbl complexes are translocated from the insulin receptor to lipid rafts and interact with flotillin. It has been reported that the $\mathrm{N}$-terminal region of CAP in 3T3-L1 adipocytes blocked glucose uptake by insulin, therefore a feature of the CAP-Cbl complex is a crucial protein for the stimulation of glucose uptake (24).

SORBS1 is located at chromosome 10q23.3-24.1 and consists of 34 exons $(20,21)$. Of 14 SNPs identified in the SORBS1 gene, two affect amino acid sequences encoding missense variants at R74W and T228A (26). However, one of the missense variants - R74W polymorphism - is not associated with obesity or diabetes. In contrast, T228A polymorphism in exon 7 of SORBS1 is a protective factor for obesity and diabetes (26). T228A results from a nucleotide substitution at 682 , changing $\underline{A} C G$ (Thr) to $\underline{G} C G$ (Ala) (26). It is implied that human SORBS1 plays a key role in the pathogenesis of disorders with insulin resistance, type-2 diabetes and obesity $(21,26)$. Previously, it was reported that the polymorphism T228A was associated with obesity and diabetes in a Chinese adult group (21). In the present study. we investigated, by means of a case-control study, whether SORBS1 is associated with PCOS in a Korean population.

\section{Materials and methods}

Subjects. All subjects were recruited from the CHA General Hospital Fertility Center in Seoul, Korea. The patient group included 233 Korean patients with PCOS, based on the revised diagnostic criteria announced in 2003 by the American Society for Reproductive Medicine/European Society for Human Reproduction and Embryology (ASRM/ESHRE) Rotterdam consensus $(27,28)$, and the control group another 105 healthy Korean women. The clinical and biochemical characteristics of the women with PCOS and the controls are presented in Table I. Their state of health was determined by medical history, physical and pelvic examin-ation and complete blood chemistry. For the diagnostic criteria of PCOS, oligomenorrhea was defined as a reduction in the frequency of menses with intervals of 40 days to 6 months, and hyperandrogenism as serum testosterone $(\mathrm{T})>0.6 \mathrm{ng} / \mathrm{ml}$ and/or serum DHEAS $\geq 300 \mu \mathrm{g} / \mathrm{dl}(29,30)$.

Written informed consent was obtained from all of the participating women. Blood samples for molecular genetic studies were collected in tubes containing EDTA as an anticoagulant and stored at $4^{\circ} \mathrm{C}$ until use. Genomic DNA was then extracted from the blood of patients with PCOS and the controls. All PCOS patients and controls in this study were Korean women. This SNP study with human blood samples was approved by an Institutional Review Board (IRB).

Biochemical determinations. Blood samples were collected from both PCOS and control patients. Hormone and glucose levels, including plasma FSH, LH, E, PRL, TSH, DHEAS, T and fasting glucose, were measured as indicators of discrimination. Insulin was measured as previously described $(27,28)$.
Table I. Clinical and biochemical characteristics of patients for normal controls $(n=105)$ and PCOS patients $(n=233)$.

\begin{tabular}{|c|c|c|}
\hline Characteristics & $\begin{array}{l}\text { Control } \\
(n=105)\end{array}$ & $\begin{array}{l}\text { PCOS patients } \\
\quad(n=233)\end{array}$ \\
\hline No. & 105 & 233 \\
\hline BMI $\left(\mathrm{kg} / \mathrm{m}^{2}\right)$ & $\begin{array}{c}20.95 \pm 2.49 \\
(16.40-28.65)\end{array}$ & $\begin{array}{c}22.96 \pm 3.86 \\
(16.35-37.32)\end{array}$ \\
\hline Waist/hip ratio (WHR) & $\begin{array}{c}0.80 \pm 0.05 \\
(0.70-0.91)\end{array}$ & $\begin{array}{c}0.82 \pm 0.06 \\
(0.69-0.95)\end{array}$ \\
\hline $\begin{array}{l}\text { Hyperandrogenism and } \\
\text { oligo- or amenorrhea }\end{array}$ & $\begin{array}{c}\mathrm{n}=0 \\
(0.00 \%)\end{array}$ & $\begin{array}{c}\mathrm{n}=31 \\
(13.30 \%)\end{array}$ \\
\hline $\begin{array}{l}\text { Hyperandrogenism } \\
\text { and polycystic ovaries }\end{array}$ & $\begin{array}{c}\mathrm{n}=0 \\
(0.00 \%)\end{array}$ & $\begin{array}{c}\mathrm{n}=22 \\
(9.44 \%)\end{array}$ \\
\hline $\begin{array}{l}\text { Oligo- or amenorrhea } \\
\text { and polycystic ovaries }\end{array}$ & $\begin{array}{c}\mathrm{n}=0 \\
(0.00 \%)\end{array}$ & $\begin{array}{c}n=158 \\
(67.82 \%)\end{array}$ \\
\hline $\begin{array}{l}\text { Hyperandrogenism, } \\
\text { oligo- or amenorrhea } \\
\text { and polycystic ovaries }\end{array}$ & $\begin{array}{c}\mathrm{n}=0 \\
(0.00 \%)\end{array}$ & $\begin{array}{c}\mathrm{n}=22 \\
(9.44 \%)\end{array}$ \\
\hline FSH levels (mIU/ml) & $\begin{array}{c}6.42 \pm 1.82 \\
(3.00-11.50)\end{array}$ & $\begin{array}{c}5.34 \pm 1.88 \\
(1.00-19.90)\end{array}$ \\
\hline LH levels (mIU/ml) & $\begin{array}{c}3.30 \pm 1.62 \\
(1.00-7.10)\end{array}$ & $\begin{array}{c}6.73 \pm 4.67 \\
(1.00-25.00)\end{array}$ \\
\hline $\mathrm{E}_{2}$ levels (pg/ml) & $\begin{array}{l}31.47 \pm 15.13 \\
(5.00-64.10)\end{array}$ & $\begin{array}{l}36.93 \pm 34.58 \\
(5.00-88.50)\end{array}$ \\
\hline Prolactin levels (ng/ml) & $\begin{array}{c}13.24 \pm 7.48 \\
(4.10-46.40)\end{array}$ & $\begin{array}{l}13.42 \pm 9.64 \\
(2.30-72.20)\end{array}$ \\
\hline TSH levels $(\mu \mathrm{IU} / \mathrm{ml})$ & $\begin{array}{c}1.88 \pm 0.94 \\
(0.03-4.06)\end{array}$ & $\begin{array}{c}2.25 \pm 1.43 \\
(0.46-10.45)\end{array}$ \\
\hline DHEA-S levels $(\mu \mathrm{g} / \mathrm{dl})$ & $\begin{array}{c}153.03 \pm 56.46 \\
(67.20-257.40)\end{array}$ & $\begin{array}{r}194.07 \pm 75.54 \\
(45.30-377.20)\end{array}$ \\
\hline Testosterone (ng/ml) & $\begin{array}{c}0.21 \pm 0.14 \\
(0.01-0.54)\end{array}$ & $\begin{array}{c}0.38 \pm 0.21 \\
(0.06-0.86)\end{array}$ \\
\hline
\end{tabular}

Genetic analysis. Exon 7 of the SORBS1 gene was amplified by polymerase chain reaction (PCR) using 5'-TACCTCAC TGCATGCCCACTCTC-3' as the forward and 5'-GACTGC TGGGAGGAGACATTAGAA-3' as the reverse primer in a total volume of $25 \mu \mathrm{l}$. Cycling parameters were denaturation at $94^{\circ} \mathrm{C}$ for $5 \mathrm{~min}, 30$ cycles at $94^{\circ} \mathrm{C}$ for $40 \mathrm{sec}$ for denaturation, $68^{\circ} \mathrm{C}$ for $40 \mathrm{sec}$ for annealing, $72^{\circ} \mathrm{C}$ for $40 \mathrm{sec}$ for extension and $72^{\circ} \mathrm{C}$ for $5 \mathrm{~min}$. Following PCR amplification, the PCR products were purified using a PCR purification kit (AccuPrep, Bioneer, Daejeon, Korea) and digested with Kas I (New England Biolabs, Beverly, MA, USA) for $3 \mathrm{~h}$ at $37^{\circ} \mathrm{C}$. DNA fragments were electrophoresed on a $2 \%$ agarose gel containing ethidium bromide and visualized with an ultraviolet transilluminator. The Kas I G $\underline{G} C G C C$ revealed that the restriction site contained $A$ allele (Fig. 1A), therefore a single 
A

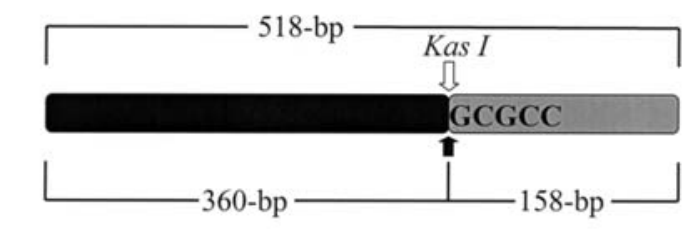

518-bp : Homozygosity for the A allele

360-and 158-bp : Homozygosity for the G allele

518-, 360-, and 158-bp : Heterozygosity for the A and G allele
B

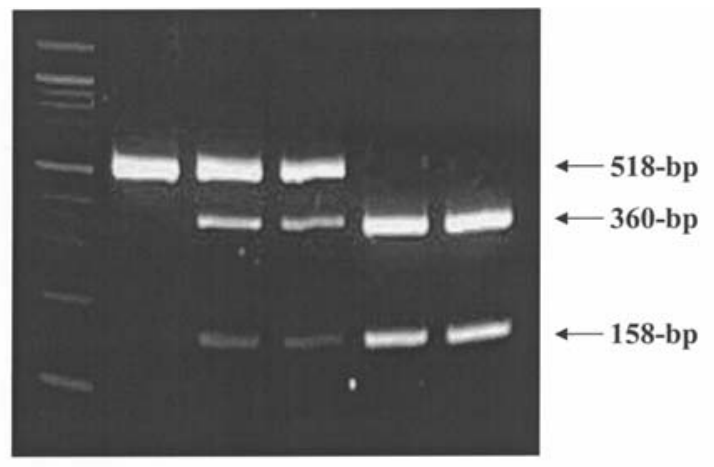

Lane 1: AA Lane 2: AG Lane 3: AG

Lane 4: GG Lane 5: GG

Figure 1. (A) Structure of the SORBS1 gene. Arrow indicates the restriction of the SORBS1 gene. The site of the $G$ allele is marked by an arrow. When the sequence has the $G$ allele, Kas I restricts the site. The products are two fragments, 360 and 158 bp. The $A$ allele makes only one fragment, 518 bp. (B) $A / G$ polymorphism in the SORBS1 gene. The $G$ allele has been restricted by Kas I. Shown is $2 \%$ agarose gel electrophoresis with ethidium bromide staining following Kas I digestion of the PCR product. The single band with 518 bp indicates an A/A genotype. Homozygosity of the $G$ allele has two bands of 360 and 158 bp. The $A / G$ type is indicated by three bands of 518,360 and $158 \mathrm{bp}$.

518-bp (base pair) band indicates homozygosity for the $A$ allele. The presence of two fragments, 360 and $158 \mathrm{bp}$, indicates homozygosity for the $G$ allele. Three bands, corresponding to 518,360 , and $158 \mathrm{bp}$, indicate heterozygosity for the $A$ or $G$ allele (Fig. 1B).

Statistical analysis. Statistical analysis was performed using Hap Analysis (31), Haploview Ver. 3.32 (2006) and SAS Ver. 9.1 (2006). Logistic regression and the $\chi^{2}$ test were used to analyze the association between the two groups. A p-value of $<0.05$ was considered statistically significant.

\section{Results}

We followed the diagnostic criteria of the ASRM/ESHRE Rotterdam consensus of 2003 regarding PCOS $(27,28)$. According to their criteria, PCOS is diagnosed when the phenotypes of patients are found within two of three criteria, oligo- or menorrhea, clinical or biochemical hyperandrogenism and ultrasonographic polycystic ovarian morphology $(27,28)$. We therefore looked for symptoms, body mass index (BMI), waist/hip ratio and hormone levels, including $\mathrm{FSH}, \mathrm{LH}, \mathrm{E}_{2}$, prolactin, TSH, DHEA-S and testosterone levels (Table I). There were no significant differences between the clinical and biochemical features of our control and PCOS study groups. However, levels of TSH, testosterone and DHEA-S were slightly higher in the PCOS patient group than in the control group (Table I), and levels of LH were increased twice as much in PCOS patients than in the controls (Table I). Of the PCOS patients, 31 (13.3\%) had hyperandrogenism and oligoor amenorrhea, $22(9.44 \%)$ hyperandrogenism and polycystic ovaries (PCOS), 158 (67.82\%) oligo- or amenorrhea and PCOS and $22(9.44 \%)$ hyperandrogenism, oligo- or amenorrhea and PCOS (Table I).

In order to analyze the frequency of genotypes for SNP in exon 7 of SORBS1 gene, we used 233 samples from patients with PCOS and 105 samples from controls. Our hypothesis was that PCOS might be caused by the aberrant expression of genetic factors, such as glucose-stimulation and secretion and/ or stimulation of insulin resistance (10-12). A number of SNPs in the genes encoding the proteins involved in glucose uptake and/or insulin resistance were investigated. One of the SNPs in the SORBS1 gene was expected to lead to a missense variant, T288A ( $A \rightarrow G$ variant). This missense variant is recognized by the restriction enzyme, Kas I. We therefore investigated the frequency of three bands, 518, 360 and $158 \mathrm{bp}$, by restriction fragment length polymorphism (RFLP) analysis. Three genotypes were present in exon 7 of the SORBS1 gene (Table II). The variant of SORBS1, $A \rightarrow G$, was confirmed by digestion with Kas I. Homozygotes of the $G$ allele did not differ significantly between the PCOS patient $(0.9 \%)$ and control $(0.9 \%)$ groups. In contrast, the rate of $A / G$ genotype was twice as high in PCOS patients $(23.2 \%)$ than in the control group patients (12.4\%), and the frequency of the $A / A$ genotype was similar in the PCOS $(75.9 \%)$ and control (86.7\%) groups, as shown in Ta ble II.

PCOS patients were associated with a single variant of the $G$ allele in SORBS1, therefore exon 7 in SORBS1 in effective glucose uptake is significantly associated with PCOS patients. We found an association between the frequency of co-dominant alleles $(\mathrm{p}=0.040, \mathrm{OR}=1.88)$ and recessive alleles $(\mathrm{p}=0.027, \mathrm{OR}=2.06)$ in the PCOS patient and control groups. In addition, using the Haploview analysis, we found that the frequency of individual $A$ and $G$ alleles is significantly associated with a variant, $A \rightarrow G(\mathrm{p}=0.039)$. As a result, we concluded that the $A \rightarrow G$ variant, a T228A missense, in SORBS1 is associated with PCOS patients in a Korean population.

\section{Discussion}

It has been reported that patients with PCOS frequently suffer from obesity, type- 2 diabetes, glucose tolerance and insulin resistance (1-4). These diseases are caused by the aberrant expression of target genes in PCOS patients. Of these, it has 
Table II. Allele frequencies of $A / G$ polymorphism in exon 7 of the SORBS1 gene in PCOS patient ( $\mathrm{n}=233)$ and control ( $\mathrm{n}=105)$ groups.

\begin{tabular}{|c|c|c|c|c|c|c|c|c|}
\hline \multirow[b]{2}{*}{ Genotype } & \multirow[b]{2}{*}{$\begin{array}{c}\text { Case } \\
(\mathrm{PCOS} \%)\end{array}$} & \multirow[b]{2}{*}{$\begin{array}{c}\text { Control } \\
(\%)\end{array}$} & \multicolumn{2}{|c|}{$\begin{array}{c}\text { Co-dominant } \\
(A A \text { or } A G \text { or } G G)\end{array}$} & \multicolumn{2}{|c|}{$\begin{array}{c}\text { Dominant } \\
(A A+A G \text { or } G G)\end{array}$} & \multicolumn{2}{|c|}{$\begin{array}{c}\text { Recessive } \\
(A A \text { or } A G+G G)\end{array}$} \\
\hline & & & $\begin{array}{c}\text { OR } \\
(95 \% \mathrm{CI})\end{array}$ & P-value & $\begin{array}{c}\text { OR } \\
(95 \% \mathrm{CI})\end{array}$ & P-value & $\begin{array}{c}\text { OR } \\
(95 \% \mathrm{CI})\end{array}$ & P-value \\
\hline AA & $\begin{array}{c}177 \\
(75.9)\end{array}$ & $\begin{array}{c}91 \\
(86.7)\end{array}$ & & & & & & \\
\hline $\mathrm{AG}$ & $\begin{array}{c}54 \\
(23.2)\end{array}$ & $\begin{array}{c}13 \\
(12.4)\end{array}$ & $\begin{array}{c}1.88 \\
(1.03-3.44)\end{array}$ & 0.04 & $\begin{array}{c}0.90 \\
(0.08-10.04)\end{array}$ & 0.93 & $\begin{array}{c}2.06 \\
(1.09-3.89)\end{array}$ & 0.027 \\
\hline GG & $\begin{array}{c}2 \\
(0.9)\end{array}$ & $\begin{array}{c}1 \\
(0.9)\end{array}$ & & & & & & \\
\hline Total & 233 & 105 & & & & & & \\
\hline
\end{tabular}

been suggested that the abnormal expression of SORBS1 is a cause of pathogenesis in PCOS (20). This results in abnormal glucose uptake and effective insulin resistance. SORBS1 is one of the target genes for PCOS patents, indicating that it is an important adaptive protein in the insulin-signaling pathway (20-26). SORBS1 plays a role in glucose uptake or insulin resistance in PCOS patients. An association study of the Chinese population reported that a missense mutation in SORBS1, T228A, is protective against obesity and insulin resistance (21). SORBS1 contains a significant sequence homology with the Sorbin and SH3-domain in the C-terminus (21). In this study, we investigated the association between the T228A polymorphism in exon 7 of the SORBS1 gene and PCOS in a Korean population group. A previous report has demonstrated that the T228A variant of the SORBS1 gene has a major effect on obesity and insulin resistance in Western Pennsylvania in the United States (20).

In our study, we examined whether there is relationship between the SORBS1 genotype and PCOS patients in a Korean population group. The frequency of recessive, $A A$ or $A G / G G$ genotypes is significantly associated with PCOS patient and control groups (Table II). We also performed statistical analysis, using logistic regression with a Hap analyzer as described previously, to identity whether there is relationship between the SORBSI genotype and PCOS patients (31). The statistical analysis revealed that there is an association between the frequency of co-dominant and recessive alleles in SORBS1 and PCOS in a Korean population. For the association test of $A$ and $G$ alleles, we performed a Haploview analysis. The results revealed that the frequency of minor allele $G$ is associated with PCOS ( $\mathrm{p}=0.039)$. This suggests that a variant of minor allele $G$ may cause pathogenesis in PCOS. These results suggest that there is a significant association between a variant of the SORBS1 genotype, $A \rightarrow G$, and PCOS patients in a Korean population (Table II), and that it affects insulin-stimulated glucose uptake, playing a key role in PCOS.

A previous report revealed that the T228A variant of exon 7 in the SORBS1 gene is associated with obese populations (26). The frequency of SNPs in the SORBS1 gene may differ according to various standards of sampling. Since PCOS may result from various factors, analysis of the association with various angles of sampling is required. Further association analysis is therefore required for obese populations according to their levels of insulin and the presence and/or absence of hyperandrogenism in obese PCOS subjects. Since an association has been found between a number of PCOS patients and insulin-stimulated glucose uptake, candidate genes for PCOS involved in the insulin signaling pathway should be investigated in various ethnic backgrounds. Data from such genetic association studies will provide insight into the role of these genes in the pathogenesis of PCOS. In order to develop therapeutic approaches, these association studies need to be defined through the investigation of large populations of PCOS patients of different ethnicities.

\section{Acknowledgments}

We would like to thank the members of the Fertility Center and Cell and Gene Therapy Research Institute at Pochon CHA University and CHA General Hospital. We also thank Dr Sophia Chen at NIH in MD, USA for her critical comments on the manuscript. This study was supported by a grant from Korea Health 21 R\&D Project, Ministry of Health and Welfare, Republic of Korea (01-PJ10-PG6-01GN13-0002).

\section{References}

1. Sheehan MT: Polycystic ovarian syndrome: diagnosis and management. Clin Med Res 2: 13-27, 2004.

2. Faloia E, Canibus P, Gatti C, Frezza F, Santanqelo M, Garrapa GG and Boscaro M: Body composition, fat distribution and metabolic characteristics in lean and obese women with polycystic ovary syndrome. J Endocrinol Invest 27: 424-429, 2004.

3. Apridonidze T, Essah PA, Iuorno MJ and Nestler JE: Prevalence and characteristics of the metabolic syndrome in women with polycystic ovary syndrome. J Clin Endocrinol Metab 90: 1929-1935, 2005.

4. San Millan JL, Corton M, Villuendas G, Sancho J, Peral B and Escobar-Morreale HF: Association of the polycystic ovary syndrome with genomic variants related to insulin resistance, type 2 diabetes mellitus, and obesity. J Clin Endocrinol Metab 89: 2640-2646, 2004. 
5. Byun EK, Kim HJ, Oh JY, Hong YS and Sung YA: The prevalence of polycystic ovary syndrome in college students from Seoul. J Kor Soc Endocrinol 20: 120-126, 2005.

6. Futterweit W: Polycystic ovary syndrome; clinical perspectives and management. Obstet Gynecol Surv 54: 403-413, 1999.

7. Knochenhauer ES, Key TJ, Kahsar-Miller M, Waggoner W, Boots LR and Azziz R: Prevalence of the polycystic ovary syndrome in unselected black and white women of the southeastern United States: a prospective study. J Clin Endocrinol Metab 83: 3078-3082, 1998.

8. Lee EJ, Oh B, Lee JY, Kimm K, Lee SH and Baek KH: A single nucleotide polymorphism of INSR gene for polycystic ovary syndrome. Fertil Steril (In press).

9. Lee EJ, Oh B, Lee JY, Kimm K, Park JM and Baek KH: Association study between single nucleotide polymorphisms in the VEGF gene and polycystic ovary syndrome (POCS). Fertil Steril (In press).

10. Seow KM, Juan CC, Hsu YP, Hwang JL, Huang LW and Ho LT: Amelioration of insulin resistance in women with PCOS via reduced insulin receptor substrate-1 Ser312 phosphorylation following laparoscopic ovarian electrocautery. Hum Reprod 4: 1003-1010, 2007

11. Ehrmann DA, Tang X, Yoshiuch I, Cox NJ and Bell GI: Relationship of insulin receptor substrate-1 and -2 genotypes to phenotypic features of polycystic ovary syndrome. J Clin Endocrinol Metab 87: 4297-4300, 2002.

12. El Mkadem SA, Lautier C, Macari F, Molinari N, Lefebvre P, Renard E, Gris JC, Cros G, Daures JP, Bringer J, White MF and Grigorescu F: Role of allelic variants Gly972Arg of IRS-1 and Gly1057Asp of IRS-2 in moderate-to-severe insulin resistance of women with polycystic ovary syndrome. Diabetes 50: 2164-2168, 2001.

13. Diamanti-Kandarakis E, Bartzis MI, Zapanti ED, Spina GG, Filandra FA, Tsianateli TC, Bergiele AT and Kouli CR: Polymorphism $\mathrm{T} \rightarrow \mathrm{C}(-34 \mathrm{bp})$ of gene CYP17 promoter in Greek patients with polycystic ovary syndrome. Fertil Steril 71: 431-435, 1999.

14. Carey AH, Waterworth D, Patel K, While D, Little J, Novelli P, Franks $\mathrm{S}$ and Williamson R: Polycystic ovaries and premature pattern baldness are associated with one allele of the steroid metabolism gene CYP17. Hum Mol Genet 10: 1873-1876, 1994.

15. Sanders EB, Aston CE, Ferrell RE and Witchel SF: Inter- and intrafamillial variability in premature pubarche and polycystic ovary syndrome. Fertil Steril 3: 473-478, 2002.

16. Lim SK, Kim MS, Lee SH and Baek KH: Polymorphism of CYP17 and CYP11. for polycystic ovary syndrome in a Korean population. Korean J Genetics 24: 343-348, 2002.

17. Franks S, Gharani N, Waterworth D, Batty S, White D, Willianson R and McCarthy M: Genetics of polycystic ovary syndrome. Mol Cell Endicrinol 145: 123-128, 1998.

18. Hara M, Alcoser SY, Qaadir A, Beiswenger KK, Cox NJ and Ehrmann DA: Insulin resistance is attenuated in women with polycystic ovary syndrome with the Pro(12)Ala polymorphism in the PPARgamma gene. J Clin Endocrinol Metab 87: 772-775, 2002.
19. Hansen L, Ekstrom CT, Tabanera Y Palacios R, Anant M, Wassermann K and Reinhardt RR: The Pro12Ala variant of the PPARG gene is a risk factor for peroxisome proliferatorsactivated receptor-gamma/alpha agonist inducted edema in type 2 diabetic patients. J Clin Endocrinol Metab 91: 3446-3450, 2006.

20. Witchel SF, Trivedi RN and Kammerer C: Frequency of the T228A polymorphism in the SORBS1 gene in children with premature pubarche and in adolescent girls with hyperandrogenism. Fertil Steril 80: 128-132, 2003.

21. Yang WS, Lee WJ, Huang KC, Lee KC, Chao CL, Tai TY and Chuang LM: mRNA levels of the insulin-signaling molecule SORBS1 in the adipose depots of nondiabetic women. Obes Res 11: 586-590, 2003.

22. Matson SA, Pare GC and Kapiloff MS: A novel isoform of Cblassociated protein that binds protein kinase A. Biochem Biophys 1727: 145-149, 2005.

23. Vandenbroere I, Paternotte N, Dumont JE, Erneux C and Pirson I: The c-Cbl associated protein and c-Cbl are two new partners of the SH2-containing inositol polyphosphate 5-phosphatase SHIP2. Biochem Biophys Res Commun 300: 494-500, 2003.

24. Baumann CA, Ribon V, Kanzaki M, Thurmond DC, Mora S, Shigematsu S, Bickel PE, Pessin JE and Saltiel AR: CAP defines a second signaling pathway required for insulin stimulated glucose transport. Nature 407: 202-207, 2002.

25. Alcazar O, Ho RC, Fujii N and Goodyear LJ: cDNA cloning and functional characterization of a novel splice variant of $\mathrm{c}-\mathrm{Cbl}$ associated protein from mouse skeletal muscle. Biochem Biophys Res Commun 317: 285-293, 2003.

26. Lin WH, Chiu KC, Chang HM, Lee KC, Tai TY and Chuang LM: Molecular scanning of the human sobin and SH-3-domaincontaining-1 (SORBS1) gene: positive association of the T228A polymorphism with obesity and type 2 diabetes. Hum Mol Genet 10: $1753-1760,2001$.

27. The Rotterdam ESHRE/ASRM-sponsored PCOS consensus workshop group: Revised 2003 consensus on diagnostic criteria and long health risks related to polycystic ovary syndrome. Hum Reprod 19: 41-47, 2004.

28. The Rotterdam ESHRE/ASRM-sponsored PCOS consensus workshop group: Revised 2003 consensus on diagnostic criteria and long-term health risks related to polycystic ovary syndrome. Fertil Steril 81: 19-25, 2004.

29. Kim J, Park J, Kim S, Choi Y, Shin C, Moon S, Lee Y and Chang S: Clinical study on infertile women with oligomenorrhea. Kor J Obstet Gynecol 38: 824-826, 1995.

30. Carmina E, Rosato F, Janni A, Rizzo M and Longo RA: Relative prevalence of different androgen excess disorders in 950 women referred because of clinical hyperandrogenism. J Clin Endocrinol Metab 91: 2-6, 2006.

31. Lee EJ, Yoo KJ, Kim SJ, Lee SH, Cha KY and Baek KH: Single nucleotide polymorphism in exon 17 of the insulin receptor gene is not associated with polycystic ovary syndrome in a Korean population. Fertil Steril 86: 380-384, 2006.

32. Orio F Jr, Palomba S, Di Biase S, Colao A, Tauchmanova L, Savastano S, Labella D, Russo T, Zullo F and Lombardi G: Homocysteine levels and C677T polymorphism of methylentetrahydrofolate reductase in women with polycystic ovary syndrome. J Clin Endocrinol Metab 88: 942-945, 2003. 